have been bestowed on him. Chronologically, the most important of these include: fellowship of the Royal Society (1947); fellowship of the Royal Society of Arts (1952); membership of the Académie Septentrionale, Paris (1961); membership of the Pontifical Academy of Sciences (1961); honorary fellowship of the Royal Institute of Chemistry (1963); fellowship of the Institute of Biology (1964). In 1960 he was appointed chairman of the Institute for Advanced Studios in Dublin. In 1960 the Irish Government made a special grant to institute a Unit of Cell Metabolism under his dirgctorship as part of the Medical Rosearch Council of Ireland. Now, as he leaves the chair to which he has brought such honour, it is to bo hopod that in these two capacities his active research programmes will continue, and his advice and oncouragement will continue to be available to the younger gonerations of Irish biochemists.

\section{Prof. M. G. Harrington}

Dr. M. G. Harrington, lecturer in biochomistry in University College, Dublin, has boon appointed to the chair of biochemistry in succession to Prof. Conway. A graduate in science of University College, Cork, Dr. Harrington was in 1952 awarded the travelling studentship in biochemistry of the National University of Ireland during the tenure of which he carried out, in association with Prof. E. F. Gale at Cambridge, investigations of the action of antibiotics on Gram-negative organisms. In 1954 he was appointed to the Department of Biochemistry and Pharmacology in Dublin, bocoming lecturer in biochemistry in 1958. From 1954 until 1963 he worked in collaboration with Prof. Conway on various aspects of electrolyte physiology; in particular, investigations of the uptake of sodium by frog sartorii, and the application of electron microscopy to such investigations. During 1963-64 he was visiting associate professor of physiology at 'Tufts University School of Medicine, Boston, where he carried out investigations on the fate of chromiumlabelled proteins injected intravenously in mico.

\section{Microbiology in the University of Birmingham :}

Prof. H. Smith

Dr. H. Smith, at prosent head of chemical pathology at the Microbiological Research Establishment, Porton, has been appointed to the chair of microbiology in the University of Birmingham, as from January 1, 1965, in succession to Prof. D. G. Catchoside, who has been appointed to the chair of genotics within the John Curtin School of Medical Research, the Australian National University, Canberra (Nature, 199, 536; 1963). Dr. Smith graduated in the University of London in 1942 and thon spent three years with Boots Pure Drug Co. After a brief poriod as an assistant lecturer in the Department of Chemistry at University College, Nottingham, he moved in 1947 to tho Microbiological Research Establishment, Porton. During the past seventeen years he has been concerned with various aspects of microbiology, but his most outstanding work has been concerned with the chemistry of microbial virulence. Dr. Smith is a prominent member of the Society for General Microbiology, and has bcen a member of its Council since 1960 .

\section{Deputy Director, Water Research Association:}

\section{Dr. E. Potter}

DR. E. PotTer has boon appointed to the newly established post of deputy director of the Water Research Association. Dr. Potter, who is forty-one, is a graduate of the University of London, having taken the special chemistry dogreo by part-time study in 1944. In 1940 he joired the Metal Box Co., whore he was engaged on packaging problems, and in 1947 entored the Imporial College of Scionce and Technology. There he carried out research on electrochemical kinetics, gaining his $\mathrm{Ph} . \mathrm{D}$. in 1950. Following this, ho returned to applied science and, after a year at the Paint Research Station, Teddington, he joined the then British Electricity Authority to set up a research unit for the investigation of corrosion and water chomistry in steam power plant. During tho next decade his team achieved fundamental advances in this fiold, applying them to the practice of large-scale steam genoration. His procedure for the analysis of oxygen dissolved in water, for example, is sensitive to one part in five thousand million, and by means of it tho oxidation of boilor stoel in high-temperature water could be clarified in practical detail for tho first timo. Ho received tho Beilby Memorial Award in 1957 for these and similar developments. In 1963 Dr. Potter lectured in Australia and New Zoaland, and has made many other technical visits, notably to the United States and the U.S.S.R.

\section{Science in Parliament:}

Aircraft Industry

In a statement to the House of Commons on December 9 , the Minister of Aviation, Mr. R. Jonkins, announced that Lord Plowden had accepted the Government's invitation to serve as chairman of a committee to consider the future place and organization of the aircraft industry in relation to the general economy of Britain. The committeo would take into account the demands of national defence, export prospects, the comparable industries of other countries and the relation of the industry with Government activities in aviation, and would make recommendations on any steps and measures necessary. The members of the committee would include Mr. Aubrey Jones, Mr. A. Albu, Mr. D. H. Barran, Mr. F. Hayday, Admiral of the Floet Sir Caspar John, Mr. C. McMahon and Sir William Penney, with Mr. N. Craig as secretary. In reply to questions Mr. Jenkins said that the committee would review the whole field of the aero-space industry, and its deliberations would not postpone decisions on projects already under review. It did not replace the Transport Aircraft Requiremonts Committee. A similar statement was made in the House of Lords by Lord Shackleton, who added, in reply to a question, that as full an account of the committee's report would be published as matters of national security and commercial confidence allowed.

Manpower Research Unit

IN reply to a question in the House of Commons on December 7, the Minister of Labour, Mr. R. J. Gunter, said that the future programmo of the Manpower Research Unit would include full consideration of the effects of automation on manpower: he would himself keep under roviow the neod for further work on the effects of human relations in industry. The Unit was exploring the possibilities of manpower forecasts on the basis of the estimated trends in output and productivity, including the effects of automation. Moroover, it was planning to follow its current studies of changes in the occupational structure of the metal industry and the effect of computers on office omployment with new studies of the changing structure of particular industries, and on the introduction of particular new techniques.

Solway Barrage

IN reply to a question in the House of Commons on Decembor 9, the Minister of State for Scotland, Mr. G. Willis, said that a preliminary examination had already been made of the Solway Barrage proposals. The new step was for the new planning machinery to examine the project, along with similar proposals for Morecambo Bay, in the context of the very substantial and competing claims on the nation's capital investment resources over tho coming yoar. The Scottish Dovolopment Group had already had discussions with local authorities on both sides of the Border and also with the North West Study Group on this matter, as well as discussions with Dr. R. L. Drew and experts from the University of Strathclyde. 